\title{
International oil companies, US Government and energy security policy: an interest-based analysis
}

\author{
Vlado Vivoda \\ Centre for International Risk, \\ School of Communication, International Studies and Languages, \\ A1-03, Magill Campus, University of South Australia, \\ G.P.O. Box 2471, Adelaide, SA 5001, Australia \\ E-mail: vlado.vivoda@unisa.edu.au
}

\begin{abstract}
This article evaluates the importance of US international oil companies (IOCs) for US energy security and is particularly important given the absence of scholarly analysis of the subject area in both the energy security and international business literature. The analysis suggests that the interests of US IOCs and the US Government have not been exclusively aligned and that the two sides have historically, in most cases, acted independently in pursuit of their interests. The IOCs act in harmony with the US foreign and energy security policy only when their interests are congruent, or under severe threat such as that of legal action. The US IOCs have historically played a very limited role in enhancing US energy security. In recent years, to the extent that they have been unable to secure access to new oil reserves and increase their oil production, they are not supporting US energy security interests.
\end{abstract}

Keywords: energy security; home governments; interests, international oil companies; IOCs; multinational corporations; oil industry; US Government policy; International Journal of Global Energy Issues.

\begin{abstract}
Biographical notes: Vlado Vivoda is a Research Fellow at the Centre for International Risk, School of Communication, International Studies and Languages, University of South Australia, Adelaide, Australia. He received his PhD from Flinders University. He teaches undergraduate courses in international relations and international political economy. In 2008 , he published a book on political bargaining in the contemporary oil industry. $\mathrm{He}$ has published on energy-related issues in journals such as Energy Policy, New Political Economy, Minerals and Energy and The Australian Journal of International Affairs.
\end{abstract}

\section{Introduction}

Energy security has a different meaning for different countries (Müller-Kraenner, 2007). For importers, such as the USA, it can generally be understood as insurance measures taken against the risks of harmful energy import disruptions, which cause the loss of economic welfare (Bohi and Toman, 1996; Lesbirel, 2004). Although, governments 
define energy security differently, depending on their status as a net exporter or importer, an importing government enhances its own country's energy security by ensuring a reliable supply of energy at reasonable prices to support the economy and industry (Dorian et al., 2006).

Alhaiji (2007) points out that policy maker limit the concept of energy security to oil, and this is unsurprising. Oil is the key to energy security of energy importing countries, and concerns about the security of oil imports dominate policy thinking. Moreover, the vast majority of the literature on energy security focuses on oil (Fried and Trezise, 1993; Stringer, 2008). It has been deemed the most important traded commodity in the world economy (Noreng, 2002). With a $35 \%$ share in 2008 , oil is the world's most widely used source of energy, and with 2,700 million tons of crude oil and petroleum products traded in 2008 - four times more than natural gas and LNG trade combined - it is the most traded energy resource (BP, 2009). Moreover, the oil market is the most imbalanced of all energy markets. Asia-Pacific, Europe and North America consume approximately $80 \%$, while controlling only $10 \%$ of the world's oil reserves. At the same time, Africa, the former Soviet Union, the Middle East, and South America consume 20\%, while controlling $90 \%$ of the world's remaining oil reserves (BP, 2009). Finally, a majority of key oil exporters, particularly those located in the Middle East, Africa or Latin America, suffer political instability or have a high risk potential for it, and this places importers at risk.

The most common measures utilised by oil-importers to enhance energy security, inter alia, include diversification of oil import sources, diversification of types of fuels used, diversification of transport routes, securing access to energy at source (i.e., through equity oil), energy conservation, energy efficiency, technological innovation, stockpiling, increased domestic production, increasing international cooperation among the importers, improving political relations with the exporters, and maintaining close relationship with, or control of oil companies based in the importing country. Given that energy security has a different meaning for different countries, it is logical that reliance on international oil companies (IOCs) or national oil companies (NOCs) to enhance energy security is assigned a different level of importance in their energy security strategies and/or policies.

The IOCs, which are also referred to as the majors or 'Big Oil', have a significant proportion of the exploration, oil and gas producing, oil refining, chemical and marketing operations in numerous countries. They are the biggest private oil companies whose operations stretch to every continent and, in some cases, to over 100 countries and territories. Nowadays, five corporations are regarded as majors: ExxonMobil, Chevron, BP, Royal Dutch/Shell, and Conoco Phillips. They are all headquartered or maintain a strong presence in the USA and are responsible for transporting significant volumes of crude oil and refined petroleum product imports to the USA. The majors account for $13 \%$ of world oil production, $21 \%$ of refining, and $35 \%$ of product sales (Parra, 2004).

Traditionally, the majors were very powerful actors in the international political economy and have often been more powerful than some states, as their revenues were regularly higher than those of many small and medium sized states. In recent years, the IOCs have represented half of the world's top ten MNCs by revenues and profits. As a group, the five major companies represent more than $50 \%$ of the market capitalisation of all publicly traded oil stocks (Bozon et al., 2005).

Some argue that in the USA, a country that imports two-thirds of the oil it consumes the IOCs have historically played an important energy security and foreign policy role (Gilpin, 1975; Myers Jaffe and Soligo, 2007). After World War II, through their 
extensive development of Middle Eastern and other non-Western sources of oil, IOCs guaranteed the USA and the rest of the non-Communist world a secure supply of relatively cheap oil (Gilpin, 1975). Since World War II and until the 1970s, there has been an almost hand-in-glove relationship between US IOCs and the state department for the purpose of meeting US foreign policy objectives in the Middle East (see US Congress Subcommittee on Multinational Corporations, 1975). Myers Jaffe and Soligo (2007) argue that in the 1980s, following the oil crises, exploration spending by IOCs spurred a large increase in non-OPEC oil production, promoting diversity of supply and enhancing US energy security in the 1980 s and 1990s. Since the 1973 oil crisis, as a key element in its energy security strategy, the USA, the world's largest oil importer, has actively pursued an oil import diversification policy. It has increased its imports from regions outside of the Middle East, particularly from South America, but also from Africa, Europe and in more recent years, from Central Asia. Most importantly, the pursuit of a hemispheric energy policy involving Canada, Mexico and the rest of Latin America, has been considered a cornerstone in ensuring US energy security and reducing dependence on oil imports from the Middle East (Salameh, 2003). Thus, increased IOC exploration and production in non-OPEC regions promoted US diversity of supply and enhanced US energy security throughout the 1980s and 1990s.

Others argue that MNCs and home governments have unique attributes and goals and thus operate under different assumptions, serve different constituencies, have different geopolitical spans, and work toward the attainment of different goals (Hamel, 1980). Against this background, the IOCs do not, and cannot play an important energy security role for home governments, including the USA. The aim of this article is to determine what role the US IOCs have historically played, and currently play, in enhancing US energy security. The discussion of the relationship between the US Government and the major IOCs, and the implications of this relationship for the US energy security, is absent from the literature on energy security. Even the authoritative volume by Kalicki and Goldwyn (2005) failed to examine the relationship. Moreover, while the relationship of the MNC to the host government has been widely explored in international business literature, the MNC interface with the home government has received relatively little research attention, with the exception of one section in the edited volume by Grosse (2005). When scholars have turned their attention to MNC-home government relations, the traditional points of interest have been the effects of foreign direct investment on the domestic employment level, on the general economic health of the nation (i.e., balance of payments, inflation, GDP) and on tax policy, rather than on the relation of the MNC to foreign policy and energy security.

The writing that has been done on this topic is primarily anecdotal in nature, or based on personal conjecture and extemporaneous theorising. Given the absence of scholarly analysis of the subject area in both the energy security and international business literature, in order to establish whether the US IOCs act in concert with the US energy security policy and whether they support US energy security interests, the article will synoptically review the literature and anecdotal evidence concerning the IOCs' relationship with the US Government. Based on the analysis of the relationship between the US Government and the major IOCs and of the overlap (or the lack of) between their interests, it will analyse the importance of the major IOCs to US energy security. This article, thus, attempts to distil a variety of anecdotal writings on a subject that has received virtually no rigorous research attention. This fact no doubt results from the 
difficulty inherent in collecting information on the often private intercourse of business and government in the area of foreign and energy policy. The negotiation between the US Government and international oil company executives is conducted largely 'behind the scenes' and thus, it is impossible for a researcher to gain access to the exact details of their often highly sensitive exchanges. This is particularly, so given that the US Government and major oil companies keep much of their relevant data private and confidential (Harris and Browning, 2003).

The remainder of the article is organised as follows. Section 2 develops further background, exploring the nature of the relationship between MNCs and the home government. Section 3 reviews both the theoretical arguments in favour of mutuality of their interests, and empirical evidence from the oil industry which shows the alignment of the interests. Section 4 reviews the theoretical propositions which argue against the mutuality of their interests, and analyses empirical evidence from the oil industry in order to highlight situations in which their interests have not been aligned. Section 5 analyses the findings and discusses the implications for US energy security.

\section{Theoretical examination of the MNC-home government relationship}

Generally, the relationship between the MNC and the home government is structured in two main ways (Nye, 1975). The MNC may serve, usually unintentionally, as an instrument of power by which the home government aims to influence other governments. This may be in response to legislative prohibition or selectively applied economic sanctions, or as an extraterritorial arm through which national foreign policy is implemented via the global organisational network of the MNC. According to this theoretical approach, MNCs serve, or should serve national interests of home states as instruments of economic development, as a mechanism that spreads ideology, as a provider of access to vital raw materials, and/or a tool of diplomacy. As an advocate for state support for MNCs in order to protect the USA national interest, Krasner (1978, p.39) argued that 'the state should try to maximise its control over foreign sources of raw materials by promoting [and protecting] the investment activities of its own corporations'. Since in the USA, unstable supplies and prices can upset the general functioning of the economy and strain the political system, some have suggested that it is prudent for US central decision-makers to protect US oil companies, even by the use of force (Tucker, 1975; Krasner, 1978). A number of studies have found evidence that major IOCs with diplomatic support from their home governments can resist being strong-armed out of existing contracts and/or emerge successful in negotiations with other players (Jenkins, 1986; Tétreault, 1995; Vivoda, 2008). More generally, Wells (2005) has argued that home government intervention has remained a threat and offers some protection to investors just by its existence.

Alternatively, the MNC may act independently to influence political actors and political structures within the home government and internationally. MNCs play a large role in the national economies of most developed countries. As long as those countries maintain representative governments, the interests of those companies will and, on any theory of representative government, should carry some weight, and the structural power of business would most likely influence the political process even in the absence of an organised effort. In this case, the MNC may, at its own behest, serve as an initiator of policy agenda items. 
There are various methods through which MNCs can and do influence home government policy. According to Brookstone (1976) channels of corporate influence in the formulation of government policy include: participation in, or direct access to key policy making units; recruitment of policy makers into business organisation, or vice versa; joint ventures with government; government contracts; consultation to policy making units; lobbying; bribes to government officials and, covert collusion with intelligence agencies. They also include access to key policy making units through intermediaries, foreign governments, parliamentary representatives, private foundations, study groups, trade associations, direct personal and/or group ties to policy makers, intermediary non-business groups, communicating knowingly the preference of the corporate elite to the policy makers and general public opinion voting behaviour.

Some theorists take the argument that business influences government a step further. The instrumentalist understanding of the US state's role within global capitalism assumes that the state is an instrument in hands of national elites. This theorisation of the US state and US foreign policy tends to reduce US decision-making to the economic interests of the US corporate interests, with the US state's primary function to ensure necessary conditions for profit maximisation for US corporations (Stokes, 2007).

Despite assertions that the MNC has an almost unlimited ability to set the home government's policy, and may even capture the policy making process to serve its interest, there is a definite limitation to the extent to which the MNC can impact upon the policy decision-making process. The ability of MNCs to determine home government policy is primarily limited by the fact that government policy makers must serve a variety of interests besides corporate interests. Whereas, business evaluates the desirability of particular foreign policy measures strictly on the basis of economic criteria, national policy makers must take into account many non-economic factors in policy formulation. In attempting to influence policy, the MNC finds itself competing against other interest groups, including perhaps other MNCs, with interests quite at variance with the firm's own unique interests.

\section{Mutual interests}

Theoretically, the home government and 'its' MNCs sometimes have mutual interests. Bennet (1991) suggested that the policies of the firm often conform to the economic and foreign policies of the home government since technology is often exported from the home state to the host state and profits are often repatriated back to the home state. According to Ataman (2003), MNCs sometimes expand the home state's marketing base, ensure lower priced products from the foreign subsidiaries are sent back to home country, pay taxes in their home country, and their stockholders in home country gain more profit from investments made abroad.

Some argue that in the oil industry most IOCs have an amicable relationship with their government, and unusually close relations between companies and their home governments have marked the history of the oil industry, particularly in the USA (Falola and Genova, 2005; Goel, 2004; Noreng, 2002). They suggest that while private oil companies operate independently from their national governments, they rarely act in opposition to it. Thus, according to this view, the investment decisions and interests of private IOCs tend to reflect the interests and priorities of their home governments and 
economies. Goel (2004) suggests that there even exists an implicit executive-industry bargain, in which the executive (the US President) furnishes the political, military and, to a lesser extent, economic elements necessary for the industry's international oil exploration, production and transportation functions. In turn, the oil industry acts as a foreign policy stalwart due to its technology, capital and longstanding submission to foreign policy objectives.

The home governments of IOCs profit handsomely from the majors' tax contributions, which provide further incentive to protect them. Between 1980 and 2005, oil companies directly paid or remitted more than US\$2.2 trillion in taxes, after adjusting for inflation, to US Federal and state governments, including excise taxes, royalty payments and state and federal corporate income taxes. That amounts to more than three times what they earned in profits after tax during the same period and these figures do not include local property taxes, state sales and severance taxes and on-shore royalty payments (Williams and Hodge, 2005). In 2007, ExxonMobil paid US $\$ 29.9$ billion in income taxes to various governments, up $28 \%$ over 2005 , while their profits have only increased by $12 \%$ over the same period. They have also paid US $\$ 72.7$ billion in sales and other taxes to various governments in the same year (ExxonMobil, 2008). Moreover, major IOCs are owned by the shareholders, the vast majority of whom are 'middle class' individuals holding shares through pension and mutual funds (Shapiro and Pham, 2007). Given that most of the profits from the majors' go to middle-class households with mutual fund investments, pension accounts and other personal retirement accounts, if any of the majors suffer, so will the average household.

Others argue that IOCs serve the national interests of home states by providing their home states with secure supplies of oil. While the US Government may not favour the IOCs per se, the fact that the IOCs have strong managerial competence, experience, and resources that enable them to undertake the development of new resources in foreign countries, helps meet the larger US energy security goal of diversification of the international oil supply (Myers Jaffe and Soligo, 2007). While governments seek secure and adequate supplies of oil to feed their economies, corporations need control over reserves to ensure their future profitability in order to deliver returns to their shareholders. For governments, 'secure' oil supplies often mean that these supplies are in fact part-controlled by major oil companies based in their own countries. Thus, the majors are financially and strategically important for home governments and for their citizens, and continued profitability and security of their operations is in the interest of both the home state and the IOC.

The interests of the US IOCs and the US Government have converged in numerous instances. As a result on numerous occasions throughout modern history, the US Government supported the IOCs in negotiations with other industry players and, at the same time, the US IOCs have been able to support US foreign policy without the sacrifice of profits. There are numerous examples where US foreign policy and IOC profit-making businesses were able to make a marriage of convenience. For example, during the early 1920s, central US decision-makers actively backed US oil companies in Central America, Colombia, Venezuela, Albania, and, most vigorously, the Middle East and the Dutch East Indies (today's Indonesia). Under the US Middle East policy, immediately following World War II, corporate profits of the US IOCs have been enhanced by companies acting as instruments of US foreign policy, which aimed to ensure that the prolific oil deposits in the Middle East and North Africa (MENA) were kept out of enemy hands and that they would not be used to threaten US (and Western) interests (Myers Jaffe and Soligo, 2007). 
Following the 1970s oil crises, the IOC investment in the new oil-producing areas, such as the North Sea, West Africa and Australia, was instrumental in providing a diverse supply base for the USA, thus, helping the USA in diversifying its sources of imported oil, a key facet of its energy security.

More recently when their interests were aligned, US Government support for US IOCs resulted in successful outcomes for the oil companies and this is evident from three notable episodes. In the early 1980s, the Canadian National Energy Policy (NEP), together with increased stringency of Foreign Investment Review Agency (FIRA), which monitors the entry of FDI in all sectors of Canadian economy, has widely been recognised as a surprisingly harsh and highly nationalistic policy and its implementation sparked an enormous round of protests on the part of the US IOCs. As they were not pleased with the NEP and FIRA, US IOCs and executives turned to the Reagan Administration for support, which they received, as the US Government was ideologically opposed to the interventionist nature of the NEP (Jenkins, 1986). The US Government support helped US IOCs to avoid being strong-armed out of their existing contracts in Canada. In the 1990s, aligned government-corporate interests resulted in the US Government support for US IOCs in the Caspian and this in turn ensured their success. With the fall of the Soviet Union in 1991, the USA pursued a vigorous policy of opening the countries of the former Soviet Union (FSU) to investments by Anglo-American IOCs. This was especially true in the countries of Central Asia where the construction of the Baku-Tbilisi-Ceyhan (BTC) pipeline, supported by the US Government, has helped Central Asian countries become more independent of Russia's sphere of influence, at the same time ensuring that the IOCs build and own the pipeline (Myers Jaffe and Soligo, 2007). In 2005, the political support Chevron received from the US Congress when it bid for UNOCAL ensured its success against Chinese National Offshore Oil Corporation (CNOOC), a Chinese state-owned oil company, which was able to offer a US\$2 billion higher bid due to its access to cheap loans from the Chinese Government (Vivoda, 2008). The above examples are supportive of Stopford's (2005) argument that the power of the US tilts the bargaining field in favour of US companies.

Finally, the instrumentalist 'blood for oil' thesis argues that US intervention in an oil-rich region, such as the Middle East, is designed to ensure that US IOCs dominate world markets (Stokes, 2007). The Iraq war was described as a 'war for oil' in which large IOCs and their home governments acted in secret concert to gain control of Iraq's oil reserves and to gain leverage over other oil companies (Paul, 2003). Some argue that there was a close relationship between the two Bush Administrations and the oil companies by reminding us that many high profile politicians in these administrations, in the past worked for, and while in power were closely related to, the oil industry. The first and second Bush Administrations have had many oil and energy industry connections: President Bush is a former Director of Harken Energy Corporation; Vice President Cheney is the CEO of Halliburton; and Secretary of State Condoleezza Rice is a board member of Chevron, and one of Chevron's super tankers was named after her. Moreover, financial disclosure forms reviewed by the Center for Public Integrity, a non-partisan watchdog group, reported that the top 100 officials in the first Bush Administration have had the majority of their personal investments, almost US\$150 million, in the traditional energy and natural resource sectors (Moran and Johnson, 2002). Gordon (2002) suggested that George W. Bush believed that what was best for Big Oil is best for the USA and that his whole formative world view was formed by being hip-deep in the oil 
patch. Some have even gone so far as to suggest that the major US IOCs hijacked the two Bush Administrations and have used this control to further their interests (Briody, 2004; Stern, 2005; Vidal, 2002).

\section{Diverging interests}

Multinational corporations and home governments operate under vastly different assumptions, serve different constituencies and work towards the attainment of different goals (Hamel, 1980). The multinational corporation is arguably the first truly global economic organisation in history. Numerous MNCs operate in over one hundred countries and generate revenues and profits greater than that of some nations. For example, in 2008, ExxonMobil reported the largest profits in the corporate history, US $\$ 45.2$ billion, and Royal Dutch/Shell reported the largest sales revenues in the corporate history, US $\$ 458.4$ billion. Also, in 2008 , the combined sales revenues of the top five IOCs amounted to US\$1.73 trillion, a sum greater than the GDP of Spain or Canada and their combined profits amounted to over US\$132 billion, a sum greater than the GDP of Egypt or New Zealand (Forbes, 2009; IMF, 2008).

With more or less unified global strategies, MNCs tend to be international in outlook. The criterion for corporate decision-making is the benefit which will accrue to the global organisation, rather than the benefit to be derived by any single national unit. The oft-stated goal of the MNC is the maximisation of firm wealth on a worldwide basis. As Nye (1975) points out, the significance of the MNCs 'a nationality' is that profits and growth depend on economic and political conditions in national jurisdictions other than that of the home government. The result is that MNCs gradually develop a view of their short-term interests coinciding with different governments at different times and of their long-term interests as different from the interests of any particular state. Gilpin (1975) notes that this fact encourages the MNC to maximise its freedom from the control of all governments as it strives to act solely on the basis of self-interest, unfettered by nationalistic regulation. Of further significance is the fact that the MNC serves a constituency radically different from that served by the nation-state. While the constituency of the corporation is an international assemblage of customers, suppliers, employees and stockholders, the constituency of the home government is primarily national in character, encompassing all citizens of the state.

The character of the nation-state is parochial and fiercely national. Domestic welfare is the basis for decision-making, as national executives and legislators attempt to maintain and enhance the country's economic and social well-being and security. The government serves a wide constituency, at least in the democratic countries, and the election and re-election of public officials depends on their ability to satisfy a majority of their constituency, a constituency with often heterogeneous expectations and desires, particularly in Western democracies such as the USA. The goals of the nation-state thus reflect a high degree of compromise among various subsections of the constituency, serve no easily defined economic or political principle and often do not overlap with those of an MNC. The instrumentalist thesis thus wrongly treats the USA policy making apparatus as a largely unitary bloc with a contiguous interest in US oil interventions.

The instrumentalist thesis also overlooks what Poulantzas (1978) calls the 'relative autonomy' of the state. By this Poulantzas meant that the state enjoys a degree of autonomy from the sectoral interests of its national capital as the state's primary function 
is to reproduce the necessary conditions for the long-term functioning of a given social formation. Thus, the structural requirements of the capitalist system as a whole are not necessarily synonymous with the interests of sections of multinational capital. The state's structural role is thus one of long-term political management which can be compromised by catering too strongly to the interests of a particular sector of capital (e.g., IOCs). As such, Poulantzas' theory of the relative autonomy of the state serves as a useful corrective to overly instrumentalist accounts that strip the state of any political autonomy free from the immediate requirements of the economic interests of powerful multinational corporations (Stokes, 2007).

Empirically, when activities of MNCs are analysed, it is clear that their operations create a variety of problems for home governments. Conflict between MNCs and their home governments often arises over various issues, such as taxation, trade policies, security issues and economic sanctions, where MNCs often disagree with and/or do not follow policies pursued by their home governments (Carnoy, 1993; Clark and Chan, 1995; Vernon, 1977). As a result, Western Governments do not necessarily benefit from the foreign activities of 'their' MNCs. The lack of national identity within MNCs also plays a role, since MNCs are in general losing their national identities and loyalties as they view markets from a global not local perspective (Vernon, 1998). For instance, even in the early 1970s, although, US-based MNCs were $90 \%$ or more US by equity ownership, they were just $25 \%$ US by sources of funds, less than $1 \%$ US by the identity of employees and practically $100 \%$ foreign by the identity of the governments that received their taxes (Vernon, 1971). Thus, foreign sources of funds, foreign employees, taxes paid in foreign countries and the very fact that these companies function in many different countries, result in differing interests to those of their home governments. This is particularly pronounced in the USA, since the liaison between the British, Japanese, French, German or Italian Government and their enterprises regarding their interests outside their respective home countries are much more intimate and continuous than in the case of US Government and US-based MNCs. Some European nations have developed reputations of being strong supporters of their MNCs who, in turn, have strong voices in their own government (Poynter, 1985).

The IOCs are very large and politically powerful private actors, whose primary objective is profit maximisation (Miyoshi, 1993). This objective often differs from primary objectives of their home governments. Thus, the US Government's and US IOCs' interests often diverge and the US Government support for IOCs in their dealings with foreign governments is ineffective and undesirable (Vernon, 1977). Managers of large MNCs 'have been aware that trying to pit government against government in an effort to solve their problems could have a price in terms of ill will and retaliation' [Vernon, (1977), p.262]. Even when pressure on behalf of a multinational enterprise has been applied by so powerful an advocate as the US Government, in many instances it has not been effective. When US-controlled enterprises have felt foreign governments breathing down their necks, the disposition has been to find some formula to relieve the pressure locally without inviting the US Government into the fray and unsurprisingly, strategies that involve inter-governmental threat or collaboration have taken a very low place in the list of possible responses.

Although, evidence outlined in Section 3 shows that IOCs with diplomatic support from the US Government were able to reach successful outcomes in negotiations with other actors, this is far from a foregone conclusion. The power of the US Government 
and its support for US IOCs in Venezuela in recent years were detrimental for US IOCs, who were strong-armed out of their existing contracts by the Chavéz Government (Vivoda, 2008). Direct US Government support for IOCs may indeed limit their success in bargaining and negotiations with governments of oil-exporting countries, such as Venezuela, many of whom are openly anti-US.

There are numerous episodes in which the US Government and US IOCs' interests and actions are contrasting. Day (2005, p.57) argues that although it 'depends on private companies to develop reserves and supply the nation with oil at a profit, the US Government does little to support its private oil companies both home and abroad'. Barnes (2007, p.10) suggested that 'history provides countless examples of Washington sacrificing the interests of US oil companies to broader goals'. According to Krasner (1978), in the early 1970s, US oil companies wanted support from the state against the pressure that was being placed on them by Saudi Arabia and Iran. However, US IOCs received no serious support from the US Government. The US Government did not want to resist nationalisations in many developing countries in the 1970 s due to its fear that in such a scenario they may tilt towards the Soviet Union (Barnes, 2007). Without state support, the oil companies could not resist pressures from even weak states and thus they failed to prevent price increases and nationalisation. Thus, by the mid-1970s the oil industry had to move to accommodate itself to OPEC. US policy makers were in this instance more concerned with keeping a lid on the political situation and maintaining the authority of conservative governments, such as that of the Shah in Iran and the Saudi monarch, than they were with the prerogatives of the oil companies, which were frequently ignored (Krasner, 1978).

Similar development occurred when US central decision-makers turned a deaf ear to oil company entreaties for more vigorous official backing in Mexico before World War II (Barnes, 2007; Krasner, 1978) and Peru in 1968. When US oil companies' interests were nationalised by Mexico in 1937, while the nationalisation riled relations between Mexico City and Washington, it never led to a break. The reason is clear: increasingly worried about the Nazi menace in Europe, the Roosevelt Administration wanted at all cost to avoid a restive neighbour to the South or, worse, one aligned with Hitler's Germany. In 1968, Exxon's International Petroleum Company was seized by the Peruvian Government. Exxon sought US assistance in obtaining adequate compensation for the expropriated property. US efforts to obtain relief for Exxon had to be tempered, however, by the realisation that several hundred other US enterprises in a dozen or so industries were continuing to operate in Peru and these firms were strongly against a hard line US approach (Einhorn, 1974).

In addition, US IOCs were the primary losers after voluntary, and later mandatory, oil import quotas were established by the US Government in the 1950s as they could import very limited quantities of internationally produced oil (Isser, 1996). It was against US IOCs' interests to go to Iran after Mossadeq was overthrown in 1953. The firms were not anxious to move into Iran as they had already increased production elsewhere and reintegrating Iran into the market would have presented a threat to oligopoly control (Krasner, 1978). However, they reluctantly agreed to do so and only after the anti-trust suit against them was downgraded by an order from President Truman from a criminal to a civil action and after heavy pressure from the US Government on national security concerns over Iran potentially falling to the Communist bloc if the oil production failed to be resumed (Krasner, 1978; Yergin, 1992). 
The US Government has also successfully utilised the pressure applied by US public opinion on the IOCs in order to influence private behaviour (Vogel, 1989). For example, major shifts in public opinion in response to Standard Oil's monopolistic practices and the Exxon Valdez oil spill have enabled the US Government to penalise the IOCs and/or adopt legislation that was not favoured by the oil companies. Even though oil interests may have successfully defended their agenda during a given period, their continued success was not a deterministic affair.

More recently, there was a clear divergence of interests between the major IOCs and the USA and UK Governments with regards to the 2003 War in Iraq (Vivoda, 2007). Fearing the consequences, the oil companies never supported the invasion and still remain reluctant to establish their operations in Iraq. Major US IOCs have vehemently opposed official US policy on Libya (until recently), Iran, Sudan and Iraq, which prohibited them from investing in these oil rich countries (Barnes, 2007). The fact that Iraq was subject to comprehensive trade sanctions in accordance with United Nations Security Council Resolution (UNSCR) 687 of March 1991 as well as other Security Council resolutions meant that Anglo-American companies were legally locked out of Iraq, at the time when they were facing production declines and were desperate to secure access to additional oil reserves. Meanwhile, despite the UN sanctions, Russian, French and Chinese oil companies, backed by their respective national governments, were prepared to negotiate with the Iraqi regime under the 'oil-for-food' program established under UNSCR 986 and were thus not bound by sanctions (Boon von Ochssée, 2006; Traynor et al., 2002). If the US and UK Governments' interests regarding Iraq converged with those of Anglo-American IOCs, they would have lifted the sanctions on Iraq, rather than staged an all-out invasion. Such a move would have allowed Anglo-American oil companies to compete with other companies and provided them access to Iraqi oil without the USA and UK having to go to war and that was certainly in the companies' best interests (Alhajji, 2003; Richards, 2001). Following the US-led invasion of Iraq, the IOCs have been reluctant to establish operations in Iraq due to legal uncertainty, political instability and fears about the safety of personnel (Vivoda, 2007). Sir Philip Watts, former chairman of Royal Dutch/Shell stated that Shell would not enter Iraq unless these issues were resolved and Total's Chief Executive, Thierry Desmarest, indicated that Total will not establish operations in Iraq unless it is stable (Dow Jones Financial News, 2003; The Financial Times, 2003). Even the former US Energy Secretary Samuel Bodman conceded that US oil companies were not interested in investing in Iraq before the security situation improves (Petroleum Economist, 2006)

Finally, with the recent change of government in the USA there has been a significant shift in US energy policy. Given its scepticism towards climate change and global warming, as a key energy policy objective, the Bush Administration was focussed on securing sufficient energy supplies at reasonable prices. A move away from fossil fuels and towards more climate-friendly fuels was not an energy security priority and this policy choice was favoured by the oil industry. For the Obama Administration, the stress is on energy conservation and diversification away from fossil fuels and this is not in the IOCs' interest as it jeopardises the future security of demand for their key product in the world's largest oil consuming country. Therefore, there is a clear divergence of interest between the current US Government and the major IOCs with regards to the current and future direction of US energy policy. 
The US Government and IOC interests are often not in alignment and when this has been the case, the US Government has often been unable to persuade US MNCs to adopt business strategies that fall in line with government policy. Through systematically examining the US economic sanctions efforts (Nicaragua, Libya and South Africa), Rodman (1995) showed that in no case was the USA able to persuade US firms to substitute public preferences for private ones. In the oil industry, during World War II, oil companies successfully used lobbying power in the congress to block government's efforts to use them to further security of Middle East oil supplies (Krasner, 1978). Furthermore, the US Government was impotent in using Gulf Oil, an US oil company, as a tool of foreign policy in Angola. During the Angolan civil war in 1975, Gulf Oil paid substantial royalties to the Popular Movement for the Liberation of Angola, the Soviet-backed group which eventually won the war, despite the fact that the USA opposed the Communist group and was providing support to the other side. In December 1975 , the US State Department ordered Gulf to withhold a US\$100 million payment to the Popular Movement whereupon the Popular Movement closed down Gulf's facility. However, when the state department eventually conceded that the Popular Movement had won, Gulf was able to make the payment and subsequently negotiate a reopening of its facilities (Hamel, 1980).

In another example, US IOCs involved in a number of Middle Eastern states, clearly did not support the US tilt towards Israel during the 1973 Yom Kippur War (Barnes, 2007) and the subsequent oil crisis. Several US oil companies were strongly opposed to the pro-Israeli position of the US Government regardless of the government pressure to support their position. In fact, in accordance with the Arab oil boycott, US oil companies refused to supply oil to the US military, despite the charge that the firms were not acting in the national interest (Gilpin, 1975). During the oil crisis of the 1970s, the US Government even threatened to nationalise Exxon, along with other IOCs, based on a belief that they caused a severe increase in oil prices (Falola and Genova, 2005). The 1970s oil crisis provides clear evidence that governmental use of IOCs as arms of public power has its limits. In the oil crisis, these limits were swiftly reached. Despite threats of nationalisation, the US Government did not succeed in obtaining preferential treatment from the IOCs they thought of as their own (Vernon, 1976).

\section{Conclusions}

From the above discussion, it is clear that the interests of US IOCs and the US Government have not been exclusively aligned and that, as a result, the two sides have in most situations acted independently in pursuit of their respective interests. Based on the analysis of the historical behaviour of the IOCs in relation to the US Government policy, it is apparent that they act in accord with the US foreign and energy security policy, in particular, only when it is in their interest to do so, or under severe threat such as that of legal action, e.g., in the case of Iran in 1953. It is apparent that the IOCs have not been, and cannot be used simply as, an extended arm of the US Government. Turner (1976, p.380) argues that the IOCs are 'actors with economic interests at both ends of the oil operation, and hence vulnerable to the displeasure of either set of governments'. The US IOCs are in a particularly delicate position in which they have to skilfully balance the often conflicting interests of home and host governments, while, at the same time, having to maximise their profits in order to satisfy the requirements of their primary constituents, 
the shareholders. The bottom-line is that whenever national governments aim to use multinational corporations as an executive arm carrying out national policies, they must recognise that the enterprises on which they rely have interests that extend beyond the borders of any single country, including the USA (Vernon, 1977).

Even if the US Government aims to change IOC behaviour in some of the situations in which their interests are incongruent, they must understand that, while they possess a degree of influence on their functioning, most of the time they do not have instruments of control that would allow them to force a change in private behaviour. At the same time, although the IOCs may occasionally be able to influence US foreign and energy policy and have in fact done so on a number of occasions, their ability to do so is strictly limited because the diversity of US interests limits the government's ability to respond affirmatively to all corporate requests for international intervention on behalf of a particular company or industry.

The US IOCs have historically played a limited role in enhancing US energy security. Their role was important from the end of World War II up until the 1973 oil crisis when, through their development and control of Middle Eastern and other non-Western oil, they guaranteed the USA and its allies a secure supply of relatively cheap oil. Their role was also significant in the 1980s and 1990s when the IOC investment in new oil-producing areas, such as the North Sea, West Africa and Australia, was instrumental in providing a diverse supply base for the USA, and thus, helping the US diversify its sources of imported oil, a key facet of its energy security following the oil crises of the 1970s. However, in recent years, the IOCs' legacy of assets in the Gulf of Mexico, North Sea and Alaska have rapidly moved toward natural, geologic decline. The IOCs have, due to legal and political barriers, been unable to respond to the strong market incentives by devoting a larger share of their soaring profits and cash flow to exploration of new fields in the Middle East, Africa and Latin America, regions largely closed to IOC investment, and have, in the current decade, lost much bargaining power vis-à-vis host governments and the NOCs (Vivoda, 2008, 2009). Thus, to the extent that they are unable to secure access to new reserves and increase their oil production, they are not supporting US energy security interests.

The US Government should certainly care whether the country's sources of oil supply are sufficiently diverse to prevent a single supplier or group of suppliers from exercising monopoly power, perhaps at the risk of geopolitical threats. However, it is not clear whether the US Government can or should support the US-based IOCs in securing access to more of the world's oil reserves. The recent shift in the balance of power in the international oil industry away from the IOCs may provide the US Government with the rationale to support the US-based IOCs internationally. However, such intervention is often undesirable; if requested, in most cases ineffective and counterproductive; and, given the recent US energy policy transformation with the Obama Administration acknowledging the crucial nexus between energy security and global warming, highly unlikely.

\section{Acknowledgements}

The author would like to thank the editor and two anonymous reviewers for helpful comments and suggestions. 


\section{References}

Alhajji, A.F. (2003) 'The US energy policy and the invasion of Iraq: does oil matter?', Paper Presented at the 30th Annual Energy Conference, Center for Energy and Development, April, Boulder, Colardo, US.

Alhaiji, A.F. (2007) 'What is energy security? Definitions and concepts', Middle East Economic Survey, November, Vol. 50, No. 45, p.5.

Ataman, M. (2003) 'The impact of non-state actors on world politics: a challenge to nation-states' Alternatives: Turkish Journal of International Relations, Vol. 2, No. 1, pp.42-66.

Barnes, J. (2007) 'NOCs and US foreign policy', Paper Prepared in Conjunction with an Energy Study Sponsored by Japan Petroleum Energy Center and the James A. Baker III Institute for Public Policy, Rice University, March.

Bennet, A.L. (1991) International Organizations: Principles and Issues, Prentice Hall, Englewood Cliffs, NJ.

Bohi, D.R. and Toman, M.A. (1996) The Economics of Energy Security, Kluwer Academic Publishers, Dordrecht, Netherlands.

Boon von Ochssée, T.A. (2006) 'Oil regime change in Iraq: possible strategic implications for OPEC', Clingendael International Energy Programme, CIEP 03/2006.

Bozon, I.J.H., Hall, S.J.D. and Øygard, S.H. (2005) 'What's next for Big Oil?', The McKinsey Quarterly, No. 2.

BP (2009) 'BP statistical review of world energy', available at http://www.bp.com (accessed on $4 / 8 / 2009)$.

Briody, D. (2004) The Halliburton Agenda: The Politics of Oil and Money, John Wiley and Son, New York.

Brookstone, J.M. (1976) The Multinational Businessman and Foreign Policy, Praeger Publishers, New York.

Carnoy, M. (1993) 'Multinationals in a changing world economy: Whither the nation-state', in Carnoy, M., Castells, M. and Cohen, S.S. (Eds.): The New Global Economy in the Information Age: Reflections on our Changing World, pp.45-96, Pennsylvania State University Press, University Park, PA.

Clark, C. and Chan, S. (1995) 'MNCs and developmentalism: domestic structure as an explanation for East Asian dynamism', in Kappan, T.R. (Ed.): Bringing Transnational Relations Back in: Non-state Actors, Domestic Structures and International Institutions, pp.112-145, Cambridge University Press, Cambridge.

Day, J.M. (2005) 'Can US petroleum companies compete with national oil companies?', Business Law Brief, Vol. 2, No. 1, pp.57-60.

Dorian, J.P., Franssen, H.T. and Simbeck, D.R. (2006) ‘Global challenges in energy', Energy Policy, Vol. 34, No. 15, pp.1984-1991.

Dow Jones Financial News (2003) Total to Take Part in Iraq Oil Redevelopment once Nation's Stable, 16 June.

Einhorn, J.P. (1974) Expropriation Politics, D.C. Heath, Lexington, MA.

ExxonMobil (2008) '2007 summary annual report', available at http://www.exxonmobil.com/corporate/files/news pub sar 2007.pdf (accessed on 4/2/2009)

Falola, T. and Genova, A. (2005) The Politics of the Global Oil Industry: An Introduction, Praeger, Westport, CT.

Forbes (2009) 'The global 2000: the world's biggest companies', Forbes, 4 August.

Fried, E.R. and Trezise, P.H. (1993) Oil Security: Retrospect and Prospect, Brookings Institution, Washington, DC.

Gilpin, R. (1975) US Power and the Multinational Corporation, Basic Books, New York.

Goel, R. (2004) 'A bargain born of a paradox: the oil industry's role in American domestic and foreign policy', New Political Economy, Vol. 9, No. 4, pp.467-492. 
Gordon, M.R. (2002) 'Iraq said to plan tangling US in street fighting', New York Times, 20 August Grosse, R. (Ed.) (2005) International Business and Government Relations in the 21st Century, Cambridge University Press, Cambridge.

Hamel, G. (1980) 'The multinational corporation and home country foreign policy: a research agenda', Division of Research, Graduate School of Business Administration, The University of Michigan, Working Paper No. 229, August.

Harris, R. and Browning, R. (2003) 'Global monitoring for environment and security: data policy considerations', Space Policy, Vol. 19, No. 4, pp.265-276.

International Monetary Fund (IMF) (2008) 'World economic outlook database', available at http://www.imf.org/external/pubs/ft/weo/2008/02/weodata/index.aspx (accessed on 3/2/2009).

Isser, S. (1996) The Economics and Politics of the United States Oil Industry, 1920-1990, Garland Publishing, New York.

Jenkins, B. (1986) 'Re-examining the 'obsolescing bargain': a study of Canada's National Energy Program', International Organization, Vol. 40, No. 1, pp.139-165.

Kalicki, J.H. and Goldwyn, D.L. (Eds.) (2005) Energy Security: Toward a New Foreign Policy Strategy, Woodrow Wilson Center Press, Washington, DC.

Krasner, S.D. (1978) Defending the National Interest: Raw Materials and US Foreign Policy, Princeton University Press, Princeton, NJ.

Lesbirel, S.H. (2004) 'Diversification and energy security risks: the Japanese case', Japanese Journal of Political Science, Vol. 5, No. 1, pp.1-22.

Miyoshi, M. (1993) 'A borderless world? From colonialism to transnationalism and the decline of the nation state', Critical Theory, Vol. 19, No. 4, pp.726-751.

Moran, M. and Johnson, A. (2002) 'Oil after Saddam: all bets are in', MSNBC News, 7 November.

Müller-Kraenner, S. (2007) Energy Security, Earthscan, London.

Myers Jaffe, A. and Soligo, R. (2007) 'The international oil companies', Paper Prepared in Conjunction with an Energy Study Sponsored by Japan Petroleum Energy Center and The James A. Baker III Institute for Public Policy, Rice University, November.

Noreng, Ø. (2002) Crude Power: Politics and the Oil Market, I.B. Tauris, London.

Nye, J.S. (1975) 'Multinational corporations and world order', in Ball, G.W. (Ed.): Global Companies and the Political Economy of World Business, pp.122-147, Prentice-Hall, Englewood Cliffs, $\mathrm{NJ}$.

Parra, F. (2004) Oil Politics: A Modern History of Petroleum, I.B. Tauris, London.

Paul, J.A. (2003) 'Oil companies in Iraq: a century of rivalry and war', Global Policy Forum, November.

Petroleum Economist (2006) News in Brief, No. 1.

Poulantzas, N. (1978) Classes in Contemporary Capitalism, Schocken Books, New York.

Poynter, T.A. (1985) Multinational Enterprises \& Government Intervention, Croom Helm, London.

Richards, C. (2001) 'IOCs play the waiting game', Middle East Economic Digest, 23 March.

Rodman, K.A. (1995) 'Sanctions at bay? Hegemonic decline, multinational corporations, and US economic sanctions since the pipeline case', International Organization, Vol. 49, No. 1 , pp.105-137.

Salameh, M.G. (2003) 'The new frontiers for the United States energy security in the 21st century', Applied Energy, Vol. 76, No. 1, pp.135-144.

Shapiro, R.J. and Pham, N.D. (2007) 'The distribution of ownership of US oil and natural gas companies', Report Prepared with Support from the American Petroleum Institute (API), September.

Stern, A. (2005) Who Won the Oil Wars? Why Governments Wage War for Oil Rights, Collins \& Brown, London.

Stokes, D. (2007) 'Blood for oil? Global capital, counter-insurgency and the dual logic of American energy security', Review of International Studies, Vol. 33, No. 2, pp.245-264. 
Stopford, J. (2005) 'Revisiting vital states: beyond the triangle', in Grosse, R. (Ed.): International Business and Government Relations in the 21st Century, pp.103-116, Cambridge University Press, Cambridge.

Stringer, K.D. (2008) 'Energy security: applying a portfolio approach', Baltic Security \& Defence Review, Vol. 10, No. 1, pp.121-142.

Tétreault, M-A. (1995) The Kuwait Petroleum Corporation and the Economics of the New World Order, Quorum Books, Westport, CT.

The Financial Times (2003) Oil Groups Snub US on Iraq Deals, 24 July.

Traynor, J.J., Sieminski, A., Cook, C. and Urban, M. (2002) 'Baghdad bazaar: Big Oil in Iraq', Global Equity Research, Deutsche Bank, 21 October.

Tucker, R.W. (1975) 'Oil: the issue of American intervention', Commentary, Vol. 59, No. 1 pp.21-31.

Turner, L. (1976) 'The oil majors in world politics', International Affairs, Vol. 52, No. 3, pp.368-80.

US Congress Subcommittee on Multinational Corporations (1975) 'Multinational oil corporations and US foreign policy', US Government Printing Office, 2 January.

Vernon, R. (1971) Sovereignty at Bay: The Multinational Spread of US Enterprises, Basic Books, New York.

Vernon, R. (1976) 'The distribution of power', in Vernon, R. (Ed.): The Oil Crisis, pp.245-258, W.W. Norton \& Company, New York.

Vernon, R. (1977) Storm over the Multinationals: The Real Issues, Harvard University Press, Cambridge, MA.

Vernon, R. (1998) In the Hurricane's Eye, Harvard University Press, Cambridge, MA.

Vidal, G. (2002) Dreaming War: Blood for Oil and the Cheney-Bush Junta, Nation Books, New York.

Vivoda, V. (2007) 'Major Anglo-American international oil companies and Iraq: Big Oil's 'promised land' or reality check?', The Flinders Journal of History and Politics, Vol. 24, No. 1, pp.85-109.

Vivoda, V. (2008) The Return of the Obsolescing Bargain and the Decline of Big Oil: A Study of Bargaining in the Contemporary Oil Industry, Vdm Verlag Dr. Müller, Saarbrücken, Germany

Vivoda, V. (2009) 'Resource nationalism, bargaining and international oil companies: challenges and change in the new millennium', New Political Economy, forthcoming, Vol. 14, No. 4.

Vogel, D. (1989) Fluctuating Fortunes: The Political Power of Business in America, Basic Books, New York.

Wells, L.T. Jr. (2005) 'Protecting foreign investors in the developing world: a shift in US policy in the 1990s?', in Grosse, R. (Ed.): International Business and Government Relations in the 21st Century, pp.421-462, Cambridge University Press, Cambridge.

Williams, J. and Hodge, S.A. (2005) 'Oil company profits and tax collections: does the US need a new windfall profits tax?', The Tax Foundation, Fiscal Facts, 9 November, No. 41.

Yergin, D. (1992) The Prize: The Epic Quest for Oil, Money \& Power, Free Press, New York. 